\title{
The EU as a Plural Constitutional Order: An approach to the Constitutional Treaty
}

Tamio Nakamura

\section{Introduction}

It is an unsettled question how to conceive of a growing polity called the European Union (EU) in legal terms. Now the Treaty establishing a Constitution for Europe (hereafter the Constitutional Treaty) has been signed and put forward for ratification by the twenty-five Member States, it is essential to ask how this Treaty normatively constructs the EU polity, and also inquire whether the Constitutional Treaty is the only constitutional norm on which the EU polity is to be established.

Broadly speaking, four types of approach have appeared in the debate over the normative conception of the EC/EU polity so far (Table 1).

On the current (i. e. pre-Constitutional Treaty) EC/EU, some have emphasized the ultimate significance of state sovereignty, and have classified the EC/EU essentially as an international organization of a remarkably effective kind (e. g., Hartley 1999, 2001, Denza 2002). They particularly stress the Member States' competence to establish, change and even abolish the $\mathrm{EC} / \mathrm{EU}$ by concluding treaties. In their view, the legal competence of the current $\mathrm{EC} / \mathrm{EU}$ derives from the delegation of state sovereign power to the $\mathrm{EC} / \mathrm{EU}$ by the Member States: the Member States would retain their sovereign power under the EC/EU regime, but for certain enumerated aims of the $\mathrm{EC} / \mathrm{EU}$, they would refrain from exercising their power in a way that might frustrate the aims and 
The EU as a Plural Constitutional Order: An approach to the Constitutional Treaty (Nakamura)

Table 1 Broad Categories of Approach to the EC/EU polity analysis

\begin{tabular}{|l|l|l|}
\hline Key concepts & classic Sovereignty & Sovereignty transformed \\
\hline Nation State & State Sovereignty Approach & \\
\hline European State & Super-State Approach & Functional State Approach \\
\hline Non-state polity & & Non-State Polity Approach \\
\hline
\end{tabular}

activities of the EC/EU. The logical consequence of this view would be that the EC/EU legal order derives its ultimate legitimacy from national constitutions of the Member States, and therefore would be dependent upon those national legal orders. Let us call this legal perspective on the EC/EU as the State Sovereignty Approach.

Others have argued that the $\mathrm{EC} / \mathrm{EU}$, especially the $\mathrm{EC}$, has established an autonomous and independent legal order which is distinct from those in the Member States in ever wider policy areas, now overlapping many regulatory functions of the nation-state, though the EC/EU's coercive force and public spending power may not be as fully effective and strong as the Member States'. Those who stress this autonomous and relatively effective EC/EU power to govern would conceive of the EC/EU either as an emerging federal state (Mancini 2000:51) or as a non-state polity of an original kind (sui generis) (Weiler 1998, 1999).

There are two types of emerging federal state model:(a) a model of a fully-fledged nation-state at European level (Super-State Approach); (b)a more nuanced approach, in that it stresses the separation of the state from the nation, and tries to conceive of the $\mathrm{EU}$ as a federal functional state, without nurturing a unitary civic society called "the nation" at a European level (Mancini 2000). We may call this latter approach the Functional State Approach.

The non-state perspective starts from the proposition that the present EU does not fit in any known categories of polity and that it may not develop into any one of them either. This view regards the EU as an emerging novel polity without proper categorical nomenclature. This 
position may in consequence demand a radical departure from traditional legal concepts if need be: since the EU is regarded as a non-state polity of an original kind, in analysing the EU it may not be suitable to use those legal concepts that assume nation-state polity. This position entails the scrutiny of the analytical value and effectiveness of key legal concepts like "sovereignty" and "constitution" for a non-state polity. If necessary, this position may even require the invention of new concepts for the analysis. We may call this position the Non-State Polity Approach.

While the State Sovereignty Approach and the Super-State Approach share a reliance on classic legal concepts mainly used for nation-state legal order or international legal order, both the Functional State Approach and the Non-State Polity Approach share doubts about applying to the EU classic legal concepts like "sovereignty", which have been used to analyse and describe a nation-state polity. Thus those who take either of the latter two approaches either avoid the usage of "sovereignty" as much as possible (La Torre 1999, MacCormick 1999), or use the concept with substantial reservations (Mancini 2000:53; Weiler 1999:312; Walker 2003; Barents 2004).

Given these various approaches to the legal analysis of the current EC/ EU polity, it is interesting to examine whether the new Constitutional Treaty can settle the debate. In order to consider this, the present paper starts from the understanding that the Constitutional Treaty succeeds the basic framework and legal accomplishments ("acquis communautaire") of the current EC/EU, although it adds some new features and modifies and / or clarifies some aspects of the current arrangements. Thus I will dispense with describing those points of continuation and refinements that I wrote on elsewhere. In the present paper, I will concentrate on the discussion of some important aspects of the Constitutional Treaty to define the EU polity. I will deliberately take a rather positivist method, looking only at relevant written legal provisions, so that I can show some paradoxes inherent to the Constitutional Treaty even at that positivist 
The EU as a Plural Constitutional Order: An approach to the Constitutional Treaty (Nakamura) level.

\section{Ultimate power of EU creation : State-Sovereignty Approach}

\section{(1) Analysis}

Let us start by examining who has the legal power to create and change the institutional structure of the $\mathrm{EU}$ under the Constitutional Treaty. The Treaty declares that it establishes the EU, reflecting the will of the citizens and States of Europe (Art. I-1(1)). Thus, on the face of it, the citizens as well as the States of Europe are deemed to have legal power to create the EU.

In fact, however, the power of the States enjoys by far secured recognition in the Constitutional Treaty. In the first place, the Constitutional Treaty still takes the form of an international treaty on which only the States agree. The Member States can still claim, at least formally, themselves as the masters of the EU architecture. The Constitutional Treaty also provides that the Member States confer competence on the $\mathrm{EU}$ for its purposes, and that competences not conferred upon the Union remain with the Member States (Arts. I-1(1), I-11(1)(2)). This provision suggests that the Member States have power to create the EU; that they remain states in international law even after the establishment of the EU; and that the $\mathrm{EU}$ is to be constructed as an international organisation established on the basis of delegation of competence. To reinforce this view, the Constitutional Treaty adds that any European "State" that respects and is committed to the values of the EU can join it (Arts. I-1 (2), I-58(1)) ; and that any Member State can withdraw from the EU in accordance with its own constitutional requirements (Art. I-60(1)). These Articles taken together suggest, at least formally, that the Member States have ultimate legal power to create and/or abolish the EU. This picture matches well with the State Sovereignty Approach. 
Does the Constitutional Treaty recognise in any way the legal power of the citizens in creating and changing the EU polity? It does, but only partially. Under the Constitutional Treaty (and under the current EC/EU Treaties as well), the citizens are simultaneously regarded as European as well as national citizens, but represented separately. The European Parliament represents the will of European citizens (Art. I-46(2)), while national Parliaments represent the wills of the citizens separated by nation-states (Art. I-46(3)). It is in the Treaty revision procedure that we see the respect for the wills of the national and European citizens. Alongside with any Member State or the Commission, the European Parliament on its own initiative may submit to the European Council proposals for Treaty amendment (Art. IV-443(1)). If the European Council decides by simple majority to go ahead with the procedure, a Convention shall be convened unless the European Council decides otherwise. That Convention is composed of representatives of the national Parliaments and of the European Parliament as well as those of the States and the Commission (Art. IV-443(2)). A similar procedure to this has already been used in drafting the present Constitutional Treaty: a similarly composed "Convention" was held from 2002 to 2003 on the Member States' initiative and the Convention proposed a "draft" Constitutional Treaty, followed by the Intergovernmental Conferences (IGCs), which finalised the present Treaty. Therefore it seems that the citizens' representatives at national as well as at European level have already carried out their roles, and will surely continue to do so as well in the future to develop the EU polity.

However, this does not mean that the citizens have a competing power equal to that of the States in creating and changing the EU constitution: (a) a Convention may not be convened if the European Council (which is, in effect, the representative body of the States) so decides and the European Parliament gives consent to that decision (Art. IV-443(2)). It should also be pointed out that the 2002-2003 Convention was only 
The EU as a Plural Constitutional Order: An approach to the Constitutional Treaty (Nakamura)

convened on the Member States' initiative. It is true that the Convention(s) to be convened in the future for revision of the Constitutional Treaty will become a rule, rather than an exception like the Convention of 20022003, thus it seems a step forward for the citizens of Europe, but the Member States still retain the discretion not to convene a Convention, whereas the citizens' representatives do not have the discretion not to convene an IGC!

(b) More importantly, even when a Convention is convened, the Convention's recommendation does not legally bind following IGCs which finalise the Treaty amendment (Art. IV-443 (2) (3) ; Art. I-33 (1)). Therefore, under the Constitutional Treaty, in strict legal terms, the will of the State can take precedence over that of the citizens in creating and altering the EU polity.

Admittedly a decision not to convene a Convention will require the consent of the European Parliament (Art. IV-443(2)) and any Treaty amendment requires ratification by all the Member States (Art. IV-443 (3)). At that point, European or national citizens or their representatives may reject the decision not to convene a Convention or may not ratify the Treaty amendment at their will. But that is a negative and defensive power rather than a positive and creative power. The point here is that the power of the citizens does not surpass nor compete equally with the power of the States in creating and changing the EU polity. To put it differently, the citizens' consent is certainly required to create and develop the EU, but the citizens do not have their own legal power to create the polity on an equal basis with the States. Thus it is possible to argue that the States still have superior legal power to create and alter the EU. In this sense the Member States remain the ultimate masters of the EU construction. This argument, so far, reinforces the State Sovereignty Approach. 


\section{(2) Difficulties}

Then is it appropriate to conceive of the EU established by the Constitutional Treaty as just one of many international organisations? The answer is a mixed one. As we saw above, it does have features of an international organisation: the Member States agree to establish a common organization, on a permanent basis for certain enumerated purposes, to which they confer certain powers to govern themselves. The critical point here is that under the arrangement the Member States retain the quality of states in international law, and the Constitutional Treaty confirms that that is the case for the EU Member States (e. g., Art. (I-5 (1) : "Essential State functions" are to be respected by the Union.).

A drawback of the State Sovereignty Approach is that it is essentially formal and static legal analysis; it lacks a functional perspective on the developing EU polity. It emphasises the "ultimate" legal power of creation and shows some analytical force in that respect, but hardly looks at ongoing development of the Union legal order, nor looks at developing European institutional structure de facto or de jure, nor the changes in national legal and institutional settings in correspondence with the development of the EU polity. This approach fails to analyse and explain the autonomously and spontaneously developing nature of the EU legal order. It is in these inherent dynamics that the EU shows most difference from other international organisations.

The State Sovereignty Approach hardly offers convincing analysis on the process of EU polity-making. For instance, at Amsterdam in 1997, France agreed on the EU Treaty that would, in the words of the Conseil Constitutionnel, "undermine the essential conditions for exercise of national sovereignty" (CC 97-394 DC, 31 December 1997, para. 7.) before it amended its constitutional constitution for ratification. Thus, that Treatymaking was touching on the very heart of the French nation-state, and in fact the EU Treaty was the prime mover in changing the conditions of 
The EU as a Plural Constitutional Order : An approach to the Constitutional Treaty (Nakamura)

French national sovereignty; the French concept of national sovereignty did not condition beforehand the making of that Treaty. The State Sovereignty Approach does hardly explain why this logically reversed situation could happen. The real process here was that the EU Treaty created new rules and institutions regardless of the constraints set by the French constitution, and it changed peoples' interests and expectations directly and independently, regardless of national legal conceptions.

Nor does the State Sovereignty Approach explain fully why a treaty named the "Constitution" was called for by the citizens as well as the states of Europe, especially since the 1990s, and why the treaty was concluded after the elaborate procedures of a "Convention" and two IGCs thereafter. Since, after all, that Approach treats the Constitutional Treaty as no more and no less than an international treaty, the word "Constitution" would be understood merely at a formal technical level to mean some basic norms of an international organisation. It may in consequence lead to such an observation that there is no significant difference between the "Constitution" of the International Labour Organisation (ILO) of the EU (e.g., Hartley 2004 is basically written on this view).

Here, however, we need to look more into the substance than the formal terminology of the Constitutional Treaty, because already at present the EU governance overlaps many critical policy areas of the states of Europe, and EU law does directly create or alter citizens' legal rights and duties and their expectations.

Furthermore, since the term "Constitution" has been more frequently used to represent the basic rules of a "state" from the seventeenth century onwards (van Caenegem 1995), the deliberate use of that historical term could suggest an intention on the part of the citizens and the States of Europe to build a "state" at European level. The Constitutional Treaty may reveal some important features that enable the organisation to exercise its competence functionally equivalent to a state. This is the perspective that the Super-state and the Functional State Approaches 
『日本 $\mathrm{EU}$ 学会年報』第 25 号, 平成 17 年 9 月

take. What can we see from these perspectives?

\section{Power and mode of governance : Functional State Approach}

\section{(1) Analysis}

The Constitutional Treaty contains provisions that give the EU statelike features. Many of those features are the restatements of current EC/ EU legal order, which is already functionally very similar to that of a federal state (Weiler 1999). Here I will discuss only new or remarkable features that the Constitutional Treaty adds.

Firstly, there are various new provisions that increase the structural unity of the EU. (a) Externally, the Treaty abolishes the legal distinction between the EC and the EU (Arts. IV-437, IV-438), dissolving the current pillar structure, and, instead, gives the EU a single legal personality (Art I-8) and capacity to act internationally in the whole area of Union competence that ranges from agriculture to transfrontier policing (Arts. III-303, III-323). It also creates a new office, of the Union Minister for Foreign Affairs, who is the representative for EU external activities and speaks for all with one voice in any field of Union competence (Art. I -28), including the Common Commercial Policy and the Common Foreign and Security Policy (CFSP).

(b) Internally, the Treaty provides the $\mathrm{EU}$ with an institutional framework common to all EU policy areas (Arts. I-9, I-19), thus abolishing the pillar distinction between former second and third pillar matters (CFSP and cooperation in police and criminal affairs) and former EC matters; a single budget covering all the items of Union revenue and expenditure (Art. I-52), common legal instruments to legislate on and/or to implement the Union's whole areas of policy (Art. I-33), and a common system of judicial review and supervision by the Court of Justice and the General Court (the latter currently called the Court of First Instance) of all legal instruments adopted by the EU institutions except ones adopted 
The EU as a Plural Constitutional Order: An approach to the Constitutional Treaty (Nakamura) in the field of the CFSP (Arts. I-29, III-376).

Thus, in terms of structure, the EU has now increased its unity. This is particularly the case for those matters for which the EU has exclusive or shared competences. According to the Constitutional Treaty, even in the field of the CFSP, which is neither the exclusive nor the shared competence of the Union, the Member States' unanimous decision at the European Council will be implemented by European Decisions, which bind the Member States as Union law, hence shall have primacy over the law of the Member States. This, at least in legal terms, will enhance the unity and effectiveness of the implementation of Union measures in the CFSP. At present unanimous decisions named "common strategies", "common positions" and "joint actions" in this field are being implemented by each Member State's measures separately but collectively on behalf of the Union. Thus those national measures are subject to national and international legal order rather than the Union legal order. Compared to the current legal situation, the Constitutional Treaty incorporates the implementation aspect into Union legal order, which has more effective judicial supervision over and coercive force on the Member States.

Secondly, the Constitutional Treaty provides legal norms that promote the autonomous legislative power of the EU more than the present EC/ EU Treaties do.

(a) The Constitutional Treaty indicates general objectives of promoting peace, the values of the Union and the well-being of its peoples (Art. I3). It no longer enumerates specific aims and objectives of the Community and the Union ( $c f$. current Art. 2 EU, Arts. 2, 3 EC). If one of the features of an international organisation is its specification of aims, then the EU now appears more like a "state" than an international organisation.

(b) The Treaty endows the EU with wide-ranging legislative power. The Treaty adds a number of new legal bases as well, in particular in the areas of space policy (Art. III-254), energy policy (Art. III-256), tourism 
(Art. III-281), sport (Art. III-282), civil protection against natural and man-made disasters (Art. III-284), and administrative cooperation to implement European law (Art. III-285).

(c) These ever-widening EU legislative competences are, however, differentiated in relation to the Member States broadly into three categories of "exclusive", "shared" and "supporting, coordinating or complementary" competences depending on the fields (Arts. I-12 to I-18). The categorisation largely reproduces the existing EC case-law, but modifies several points. For instance, the area of "agriculture and fisheries, excluding the conservation of marine biological resources" is now classified under "shared" competence. But the EC case-law on the Common Agricultural Policy (CAP) has established that the Member States' legislative competence should be pre-empted by comprehensive legislation by the Community (Nakamura 1993:173-186). Thus a large number of CAP matters have been treated as falling into the Community exclusive competence. For another instance, it was not clear from the existing caselaw whether that pre-empted competence might revert back to the Member States once the Community decides to cease exercising it. Interestingly, the Constitutional Treaty now provides the possibility of this reversion in the areas of "shared" competence (Art. I-12 (2)). Whether this is a re-statement of current law or amendment to it is a moot point, but my point here is that the Constitutional Treaty clearly introduces federal distribution of legislative competence between the EU and the Member States. It does not use the controversial word "federal", but euphemistically says that the Union shall exercise its competences "on a Community basis" (Art. I-1(1)).

A related larger point is that the Constitutional Treaty autonomously constructed this federal distribution of legislative competences without reference to any legal restrictions expressed in national constitutions. Now that the Constitutional Treaty indicates the "shared" competence can revert back to the Member States but presumably not the "exclusive" 
The EU as a Plural Constitutional Order: An approach to the Constitutional Treaty (Nakamura)

one, unless the Treaty is abolished, or the Member State withdraws from the EU, the delegation of national legislative competence relating to "exclusive" matters should be construed as permanent delegation, not provisional. That will constitute a permanent legal restriction on national legislative power, thus requiring national constitutional amendment if the point is not yet clearly acknowledged. Some national constitutions do not explicitly provide for federal distribution of legislative competence, even domestically. This discrepancy shows clearly that the EU legal order is being created autonomously.

(d) The Constitutional Treaty has made explicit the primacy of Union law over the Member States' law (Art. I-6), on the basis of the case-law of the European Court of Justice, but, as the wording stands, expanding the case-law beyond the current scope of application to include the area of the CFSP and cooperation in policing and criminal matters.

(e) A novelty introduced by the Constitutional Treaty is the citizens' initiative (Art. I-47(4)). A million or more EU citizens of "a significant number" of Member States are allowed to take the initiative of inviting the Commission to submit proposals. The initiative does not bind the Commission, but it normatively enriches the concept of European Citizenship in that the citizens derive from beyond national boundaries, and at the same time they directly participate in discourse at EU level.

Thirdly, judicial autonomy is strengthened. The scope and effectiveness of the rule of law in the Union by the EU courts (especially the Court of Justice) is extended.

(a) The supremacy clause is now explicitly provided for (Art. I-6), as is mentioned above.

(b) The Constitutional Treaty now incorporates the Union Charter of Fundamental Rights proclaimed in 2000 into Part II of the Treaty, to give the Charter legal force, and to regard those fundamental rights as part of the "common values" of the Union (Preamble of Part II CT). In fact, the provisions of this Charter are addressed not only to the Union institutions, 
bodies, offices and agencies but also to the Member States when they are implementing Union law (Art. II-111(1)). Since Union legal measures, whether legislative or non-legislative, are in many cases implemented by the Member States rather than directly by the Union itself, the actual legal impact of the Charter in the Member States would be greater and more profound than what one can envisage from that Article.

(c) In the field of the CFSP, the European Council now takes decisions in the form of "European Decisions" which have autonomous legal validity and effect as Union law (Arts. I-40(3), I-33(1)). These being so, they must accord with the Constitutional Treaty, especially the Union Charter of Fundamental Rights reproduced in Part II of the Treaty. Though the jurisdiction of the Court of Justice over CFSP matters is severely limited, the Court can review the legality of European Decisions adopted by the European Council that provide for restrictive measures against natural or legal persons (Art. III-376).

Fourthly, the Constitutional Treaty promotes the coercive force of Union law. During the 1990s, EU law, including case-law of the Court of Justice increased its coercive element (Haekkerup 2001): for instance, a second paragraph was added to Article $228 \mathrm{EC}$ so that the Community can fine a persistently defaulting Member State (Art. 228(2) EC); a new Article $7 \mathrm{EU}$ was introduced, which stipulates the suspension of rights of a Member State that is in a serious and persistent breach of Union principles, including democracy and respect for human rights and fundamental freedoms; and the Court of Justice established its new case-law covering Member States' liability for breach of Community law. To reinforce the trend, the Constitutional Treaty, which succeeds the legal achievements by the current EC/EU ("acquis") (Art. IV-438), now adds that a European Law of the Council may establish a European Public Prosecutor's Office from Eurojust (the national prosecutors' network organised at the Union level) in order to combat crimes affecting the financial interests of the Union (Art. III-274). The new Treaty also 
The EU as a Plural Constitutional Order: An approach to the Constitutional Treaty (Nakamura)

simplified and expedited the infringement procedure against a defaulting Member State (currently based on Arts. 226 and 228(2)), so that the Commission can ask the Court of Justice to fine a Member State which is failing to implement a European Framework Law, when the Commission brings an infringement action for the first time (Arts. III-360, 362 (3)). Currently the Commission needs to bring a first action of infringement, and then again bring a second action to ask for the fine.

\section{(2) Formal Difficulties}

Despite these features, the State Sovereignty Approach would contest that the EU under the Constitutional Treaty still falls short of satisfying the established formal criteria of a state in international law. A state as a person in international law should at least possess (a) a permanent population; (b)a defined territory; (c) a government; and (d) a capacity to enter into relations with other states (Montevideo Convention on the Rights and Duties of States (1933) Art. 1).

The EU does not even meet these minimum criteria. Assuming that the EU has its permanent population and defined territory, and even assuming that it has a government, still it does not have full capacity to enter into relations with other states: the EU does not have exclusive competence for every matter that a state would deal with. The Constitutional Treaty provides that the Union has the capacity to enter into relations with other states, but within the limits that the Constitutional Treaty provides for (cf. Art. I-13). Thus we are thrown back to the distribution of internal competence:the Union's "exclusive" legislative competence covers only the areas of customs union, internal market competition rules, euro zone monetary policy, marine biological resources conservation, and common commercial policy (Art. I-13). Those policy areas of "supporting, coordinating or complementary action" are basically reserved for the Member States' competences, and the Union's autonomous actions are strictly limited (Art. I-17). Other policy areas are classified as "shared" 
between the EU and the Member States (Art. I-14), and thus dependent on EU legislative practice. It is also noteworthy in this connection that the Constitutional Treaty provides contrasting legal effects of international agreements concluded by the Union if those relates to the CFSP or not: when international agreements are concluded in the fields other than the CFSP, those agreements are binding on the Union and the Member States (Art. III-323(2)), whereas that particular legal effect is not provided for in relation to international agreements in the field of the CFSP (Art. III-303). Therefore it is not clear if an international agreement in the CFSP field is to be a Union agreement or a collective Member States agreement or a mixed one.

If we make the criteria of a "state" more substantive, i. e., requiring a government to be autonomous, the $\mathrm{EU}$ at present or under the Constitutional Treaty would not satisfy that requirement. As I have discussed above, the $\mathrm{EU}$ is established by the states through the principle of conferral of power (Art. I-11(2)), and the Union competence does not cover every matter that a state can cover. In short, the EU has no legislative Kompetenz-Kompetenz (the original unlimited power of a legal entity to decide on its own power). It is the Member States that still remain fully-fledged "states" in international law.

Moreover, looking from the Member States' constitutional perspective, some national constitutions define the EU not as a state but as a union of states (e. g., Germany, France) (FIDE 2002 II :207). It is also important for national constitutions to note that the Constitutional Treaty confirms the following: that the Member States retain their own competence concerning the geographical demarcation of their borders in accordance with international law (Art. III-265(3)), and their own competence to define their national citizenship to which European citizenship is added (Art. I-10(1)). Indeed the Constitutional Treaty requires the Union to respect the Member States' national identities and their essential State functions, including their territorial defence (Art. I-5(1)). After all, the 
most forceful State functions of controlling its people and territory, i. e., military and police forces, still belong to the Member States, and the Union has hardly any military or police power of its own, except for the future European Public Prosecutor hinted at in the Constitutional Treaty.

To sum up, at present and under the Constitutional Treaty, the Member States have not lost their statehood in international law nor have they indicated their intention to discard their statehood in international law, it is difficult to assess the EU even, at least, as a federal state (much less so as a unitary Super-State) since a federal state shall constitute a sole person in the eyes of international law (Montevideo Convention Art. 2). It is logically impossible for the Member States to keep their statehood and their full international capacity and at the same time to belong to a federal state called the EU.

\section{(3) Functional Difficulties}

Furthermore, if we take a functional perspective, we still see two distinctive modes of governance remaining in the EU, although the current three pillar structure is formally abolished by the Constitutional Treaty. Both modes derive from the current practice but are to some extent modified by the Constitutional Treaty.

The first mode is the ex-Community mode:here the main decisionmaking procedure is that the Commission puts forward proposals and the European Parliament (EP) and the Council jointly decide on them, in principle on a majority basis (the Council takes double majority voting in principle; the EP absolute majority voting) (Arts I-34, III-396). This is a simplified co-decision procedure (renamed "ordinary" legislative procedure). The second mode is the ex-Second Pillar (CFSP) mode: its basic decision-making procedure is that the Union Foreign Minister (with or without the Commission's support) or a Member State submit proposals or initiatives and the European Council or the Council decide on them by unanimity (Art. I-40(6)). The European Commission and the EP do not 
play significant roles in decision-making in this mode. Thus the exSecond Pillar mode retains intergovernmental features of decision-making, and is applied as before to the CFSP matters. Retaining the functional distinction in this way between the ex-Community mode and the exCFSP pillar mode reinforces the above mentioned formal analysis that the Member States preserve statehood, particularly by keeping their physical coercive governing power over their nationals and territories.

The weakest point for the Super-State Approach from both formal and functional perspectives is that it presupposes one sovereign "nation" at European level. It does not correspond to the current European reality at all. The Union citizenship (European Citizenship) only arises when one has the nationality of a Member State (Art. I-10). The Union citizenship is supposed to be transnational, but born nationally in legal terms. Thus supposedly transnational European citizenship is, in normative terms, overshadowed by the nation-state nationality/citizenship. And there is no sign on the part of the Member States that they should cease to be states in order to form a super-state. Under these legal and factual circumstances, it would be too fanciful to assume the unitary European people's power to construct a polity, le pourvoir constituant européen (Weiler 2003:7-11). Its perspective has neither analytical power nor explanatory persuasiveness in the current $\mathrm{EU}$ and in the $\mathrm{EU}$ under the Constitutional Treaty. Methodologically it is doubtful too, because the history of the EC/EU so far never appears to be conclusive if the citizens and the states of Europe ever aim at a unitary European nation and statehood (Bliss 1970; Nelsen and Stubb 1998; Harryvan and van der Harst 1997). That is an open question over which the debate continues. The Super-state Approach starts from the assumption that a unitary European nation and statehood is the only target for which the citizens and the states of Europe are striving, which itself would amount to a particular political assertion.

The Functional State Approach, on the other hand, has analytical power 
The EU as a Plural Constitutional Order: An approach to the Constitutional Treaty (Nakamura)

concerning the growing Union competences and their functional distribution, but at the same time faces many difficulties. The difficulties essentially lie in its methodology of assuming statehood at European level. The assumption reduces the explanatory power of the Approach in the EU polity-making process:it does not explain why the EU still has two fundamentally different modes of governance. The assumption also invites the same criticism of methodology that was given to the Super-State Approach:it is assuming what is in dispute.

The merit of this Approach, however, is its functional perspective, which captures the ongoing interaction between the national and the European legal orders, i.e., the inherent spontaneous dynamics of the EU polity-making process. The sovereignty-bound approaches (State Sovereignty Approach and Super-state Approach) have hardly caught successfully the dynamic aspect of EU polity-making:since they assume that European power derives either from the Member States (state sovereignty) or from the Super-State (European sovereignty), they never assume two or more sovereignties are competing.

How then can we synthesize the rather paradoxical legal situation of the EU? We cannot neglect the classic sovereignty discourse as long as the Member States still keep their statehood in international law and national constitutional law. At the same time, we need to develop an analytical and explanatory legal framework for the functionally state-like, but uniquely developing polity called the EU, which classic legal concepts like sovereignty or a state do not always capture effectively. At least we should be better off if we drop the assumption of statehood at European level but keep a functional perspective and remain critical of the nationstate assumption included in many classic legal concepts. This is the method and perspective that the Non-State Polity Approach takes. 


\section{Plural Legal Orders and Interface : Non-State Approach}

\section{(1) Analysis}

Let us now proceed on the basis that the EU has its autonomous institutions and power to the extent that the establishing Treaties provide for them. Let us also assume that the Member States remain as states in international and constitutional law, thus assuming that $\mathrm{EU}$ is to be regarded as a non-state polity of an original kind (sui generis).

Under the Non-State Approach, the functional features that the Functional State Approach has identified are in principle shared, although the Non-State Approach does not consider statehood as the paradigm for the EU polity. Therefore we should now ask what, if any, unique non-state features of the EU polity under the Constitutional Treaty have, apart from those functionally state-like features.

Firstly, the Treaty recognises some direct and essential role of nonstate actors in EU governance. The quintessential example is the current special regulatory regime called the "social dialogue" (Art. 138 EC). The Constitutional Treaty also provides essentially the same regime (Arts. III211 and 212). Management and labour at the European level shall be consulted by the Commission in formulating the possible direction of Union social policy as well as specific social policy measures. If management and labour so desire, instead of making a Union law through normal legislative procedure, they can conclude private agreements between themselves which may be implemented publicly by European regulations or decisions by the Council, subject to certain requirements. It is noteworthy (a) that both parties to this regime have transnational character, i. e. they are transnationally organised by their specific interests; (b) that their transnational private rule-making directly substitutes for public lawmaking at European level.

Another similar example is the Economic and Social Committee, though 
The EU as a Plural Constitutional Order: An approach to the Constitutional Treaty (Nakamura)

this is an institution of consultation only. The Committee of the Regions would be another possible similar example, although this represents not private parties but local governments directly at European level.

What are common to all these institutionalised private or non-central government actors are (a) their representation of articulated non-state interests of their own, (b) their transnational and interest-specific character of organisation, and (c) their legally protected status by the Constitutional Treaty: they are given their legal right and interest to be consulted, and indeed disregard of the consultation procedure may lead to annulment of relevant Union actions.

Secondly, some functions and tasks of a "state" (the Member States) are now transformed by Union law to form task-specific transnational networks and institutions at European level. We may call this "normative Euro-institutionalisation of partial state function". The implication of this for the Member States is that a state no longer keeps its functional integrity even in legal terms, much less so in real terms. Some of its essential governing functions are reorganised or transformed at European level, often in tandem with creating certain European institutions or intergovernmental networks. The implication of this for the Union is that that a particular specific task does not correspond to any particular polity model, such as a Super-state model or non-state polity model. Those taskspecific public actors networked or institutionalised by the Union law are simply expected to contribute to the formulation and/or implementation of specific Union policies and legal measures.

The regime of Economic and Monetary Union (EMU) is a typical example. Here the national central banks are networked around the European Central Bank (ECB) to form the European System of Central Banks (ESCB) and through this network institution European monetary policy is formulated, implemented and monitored (Arts. III-185 to III202). It is important to remember that the system is given legally protected independence from the other $\mathrm{EU}$ and national decision-making 
processes (Arts. I-30(3), III-188). The entire task of European monetary policy is separated from national control and from normal EU political control. This regime has also been given effective legal rights to defend its own power and status (e.g., Art. III-365(3)), and the necessary legal rights of its own to implement European monetary measures (Arts. I-30 (4) (5), III-190). Thus it normatively constitutes an independent system in the EU polity, in relation to the task of European Monetary Policy. In this way, a classic "state" is normatively dissected into specific "functions" at European level, and re-organised along these functions without corresponding to any specific final polity model of the Union.

Thirdly, the Constitutional Treaty also creates the interface of EU and national legal systems. The interface thus created promotes interaction of laws of the Union and the Member States, which may result in transformation of legal concepts, and possibly legal paradigms, in national and/ or Union legal order. Interaction and transformation would be particularly promoted when both Member States' law and Union law provide a similar normative interface, i. e., national law, constitutional or ordinary, refers to Union legal order as a part of national law, and the Union law vice versa. When the interface is set up in legal terms, there would be no distinct legal boundaries drawn between the two legal systems since the legal development would become a circular process: national law to become European law to become national law, ad infinito.

(a) The example in point is the new role of national parliaments, which is indicated, if not imposed, by the Constitutional Treaty in legal terms. A Protocol attached to the Treaty introduces a new procedure to supervise the application of subsidiarity and proportionality principles in the European legislative process. Every proposal and amended proposal for European legislative acts (i. e., "European Laws" and "European Framework Laws") shall be put forward to the national Parliaments (Art. 3 Prot.), which has six weeks to examine if the proposals satisfy the principles of subsidiarity and proportionality (Art. 5 Prot.). Each national Parliament 
The EU as a Plural Constitutional Order: An approach to the Constitutional Treaty (Nakamura)

has two votes (one vote per chamber if bicameral) to show their conclusion, and if one-third or more of the total votes of all the national Parliaments indicates the non-compliance of the said principles, the proposals in question must be reviewed by the proposing Union institution, although they could be maintained if the institution has reasons to do so (Art. 6 Prot.).

The constitutional novelty of this "early warning" procedure is that the Union law now designs the suggested role of national Parliaments, whereas traditionally the role should have been for the national constitutions or national laws to prescribe. This is the interface that the Constitutional Treaty introduces. Since this early warning procedure, in effect, defines the European role of national Parliaments, national constitutions and/or laws would also have to acknowledge that European role by themselves in ratifying the Constitutional Treaty. In this way the interaction between the Union and national laws would emerge.

Looking this from a national perspective, it is possible to observe that the adoption of the early warning procedure at the Union level is in effect a Europeanisation of such national best practice as was originally developed in Denmark (Hagel \& Rasmussen 1985). Therefore the early warning procedure is seen not only a self-prophesy on the part of the Union legal order, but also a self-prophesy on the part of the national legal orders that is shared in advance before their separate national amendments take place.

It is already an established practice for the Union to adopt certain national best practices in building the Union's own governing system. The examples are the Economic and Social Committee (an advisory body in the legislative process representing various social interests: similar institutions had already been functioning in France (Art. 69 French Constitution of 1958) and in the Netherlands (Art. 79 of the Netherlands Constitution) when the original EEC was established), and the European Ombudsman (an independent watchdog over the Union administration:similar national 
institutions had already been developed in Nordic countries and in the UK) (Heede 2000).

This Union-national legal interaction might gradually bring about a fundamental change of national constitutional paradigm as well. It is not inconceivable even in the UK, where there is no written Constitution. Before and after the British accession to the EEC (1973), serious legal debate arose among constitutional lawyers in Britain (Nakamura 1993). Traditionalists argued that the legal doctrine of "Parliamentary Sovereignty" remained intact after the UK's accession: they recognised the EEC as an international organisation with delegated powers (Cmnd. 3301 (1967); Cmnd. 6003 (1975)). Based on this understanding the British Parliament reorganised its Parliamentary Committee to supervise the British government's behaviour in the Council in Brussels (Cygan 1998). This is a typical paradigm of national constitution of Westminster-type government, that the Parliament shall control and supervise the executive (national administrative institution). It never assumed any European "legislative" role for the British Parliament in national legal terms. Interestingly, however, a minority argument at that time may now sound more real and thought-provoking in the present context, to the effect that the British Parliament had changed its "manner and form" in national legislation, i. e., it changed its own definition of "Parliament", originally composed in tripartite form (the Queen, the Lords and the Commons), but after the accession it transformed itself into quadripartite form (the three original entities plus Brussels!), to the extent EEC law applied (Winterton 1976). This view suggested that the British Parliament should be involved in European legislation. If we take this view, we would be able to accommodate the "early warning procedure" in British legal terms without difficulty, whereas the traditional view may have difficulty in explaining why the delegated organ can organise its principal's own deliberation procedure and rights to vote.

(b) Another example of interface, though more gradual in its develop- 
The EU as a Plural Constitutional Order: An approach to the Constitutional Treaty (Nakamura)

ment, is the networking of national and European administrative organs for mutual cooperation, especially in implementation of Union law and/or specific policy measures (Arts. III-285, III-263, I-42). The Constitutional Treaty, for example, mandates that the Council shall adopt European regulation to ensure administrative cooperation between the relevant departments of the Member States in the "Area of Freedom, Security and Justice”, as well as between those departments and the Commission (Art. III-263). More function-specific networks in this area are the prosecutors' network called Eurojust (Art. III-273) and the national police forces' network organised under Europol at the Union level (Art. III-276).

As the task specific networks being set up, national administrations start to reorganise themselves to meet the new task more efficiently and effectively (Knill 2001). Substantive laws and/or procedural laws of each Member State are made known to all the other Member States gradually in larger volume. As this process of mutual learning goes on, mutually acceptable legal principles and/or specific rules may be shared for some specific issues in the form of Union law. Establishing network type interfaces at Union level thus promotes a cyclical process of legal interaction of Union and national laws (For examples in the field of environmental policy, Usui 2003).

(c) A less legal example of interface is the "Open Method of Coordination" (OMC). Under the OMC, depending on the policy areas, either the Council (and the European Council) or the Commission issue guidelines with targets and indicators to the Member States, and the Member States plan and implement their own national actions, annual or multiannual, which are to be monitored and assessed by the relevant Union institutions. The result of assessment will become a new basis on which to form up-dated or fresh guidelines for the next period of years. Since these "guidelines" and "action plans" are non-legal measures, interaction of the Union and the Member States' laws would seem rather unlikely de jure, but could happen de facto. 
(d) Looking at the same point from the Member States' perspective, laws of some Member States have some provisions that refer specifically to the EC and/or EU legal system so that the national authorities can, if they wish, validly take notice of the development of Union law as it happens. Examples include the German Constitution (Art. 23), the French Constitution (Arts. 88-1 to 88-4), the Irish Constitution (Art. 29(4)), the Italian Constitution (Art. 117), the Austrian Constitution (Arts. 23a to 23f), the Finnish Constitution (Arts. 93, 96, 97), Swedish constitutional law (The Instrument of Government, Chapter 10 Art. 5) and the UK's parliamentary act of constitutional importance (The European Communities Act 1973, SS. 2 and 3$)$.

Admittedly these legal provisions at present stand on the classic sovereignty theory and on the delegation of power model, to construct the legal relationship between the Member States and the EU. However, the practice of legal interaction is in effect institutionalised by the Constitutional Treaty in wider areas of law (especially in the area of Freedom, Security and Justice), and as the Constitutional Treaty explicitly adopts the model of federal distribution of power on its part, it will be likely that the national paradigm of delegation of power will lose its analytical and explanatory force, and in correspondence, functional legal analyses will gain more support in national legal thinking as well, with the result that classic idea of sovereignty is transformed to accommodate the division of governing power in different polity levels.

Fourthly, the Constitutional Treaty recognises a partial unity or differentiation rather than a uniform comprehensive unity among the Member States in some policy areas and issues. This is evident in the area of common defence policy (Art. I-41). Because some national constitutions adopt neutrality, and some Member States are bound by specific international agreements, the Constitutional Treaty provides (a) ad hoc differentiation in policy implementation (Art. III-310) and (b) permanent differentiation in policy cooperation (from policy formation to implementa- 
The EU as a Plural Constitutional Order: An approach to the Constitutional Treaty (Nakamura)

tion as a whole) in especially demanding defence tasks (Art. III-312). A similar example can be found in the Monetary Policy, where the Member States are differentiated into those whose currency is the Euro and those whose is not, the two groupings being subject to different Union rules (Arts. III-185 to III-202).

This feature of partial unity is different from the second feature: normative Euro-institutionalisation of partial state function. The partial unity relates more to the membership (hence geographical) partiality of the cooperation than the functional partiality of governance. However, both reinforce the non-uniform aspect of normative as well as functional picture of the EU polity.

While the Functional State Approach would interpret these four main features as an "unaccomplished" stage of a future state, the Non-Polity Approach would regard these as the normative features of the EU, a polity without statehood.

\section{(2) Normative Construction of the EU polity}

How then shall we construct normatively the non-state polity now called the EU, especially when taking the Constitutional Treaty into consideration?

Firstly, as is clear from what I analysed the EU from a formal legal perspective, national and international legal concepts and the national and international normative discourse based on classic sovereignty theory still remain effective in creating the EU polity. Those concepts and theory are assumed by the Constitutional Treaty itself as well:it still keeps the form of a "treaty" between states.

Secondly, however, Union law has its normative autonomy to the extent which the Constitutional Treaty and/or the current EC/EU Treaties prescribe. As I pointed out above, non-state actors have been recognised as legitimate actors in the European legislative process by Union law, and they are given their rights in Union governance directly by Union law. It 
is also pointed out that the Constitutional Treaty prescribes what national constitutions should be prescribing by themselves: the examples being the fundamental rule of the primacy of Union law over national law (Art. I6), and the suggested role of national parliaments in the European legislative process (Protocol). This is the very result of the interface happening between these separate but interlinking legal orders.

From the functional legal perspective, the autonomy of the Union legal order is now established after 50 years of practice, especially in those policy areas classified as "exclusive competence" of the Union.

Thirdly, therefore, it would be reasonable to assume that the EU constitutional order comprises two normatively separate but interlinked legal orders: the national constitutional orders on the one hand, and the Constitutional Treaty order on the other hand. These two parts make up the EU constitutional order as a whole. The national legal order at present maintains classic sovereignty discourse in national and international law, whereas the Union legal order has developed its own discourse on its power that is inspired by comparative legal analysis of national laws and international law as well as its own didactic interpretation of positive law such as the Constitutional Treaty. Mainly by setting up the Unionnational law interface and promoting the interaction between the two legal orders, the Union power discourse may transform the classic national sovereignty concept firstly functionally, and then eventually formally as well.

So far the mixture of these discourses has not produced a fixed model of the EU polity, which at best is described in the negative form: not a state in international law, nor an international organization set up between the states. It is a unique entity of a non-state kind that contains an inherent system of legal interaction and concept transformation. In this ultimate sense, it would be rather meaningless to discuss whether the Constitutional Treaty is a "constitution" or a "treaty". It is neither of them, because the paradigm of judgment itself is being transformed by 
The EU as a Plural Constitutional Order: An approach to the Constitutional Treaty (Nakamura) the system that the Constitutional Treaty establishes.

\section{Conclusion}

The EU at present, and under the Constitutional Treaty, is best seen as a plural constitutional order in normative terms as well as in practice. The Constitutional Treaty is a partial constitution. It mainly represents the Union part of the whole EU constitutional order, and the national constitutions mainly represent the national parts. Both have, however, interlinking norms to recognise each other to form a polity as a whole.

Since the Member States' constitutions still use the concept of sovereignty in its classic sense, transnational arrangements made by the Member States based on international law could still also form a part of the EU constitutional order. This would imply that even after the adoption of the Constitutional Treaty, other transnational legal arrangements made in the form of international law by the Member States could be added to the EU to form the more developed EU. In that sense, the whole EU constitutional order has some parts unwritten (or not yet written).

The Union motto of unity in diversity will be achieved by the interaction and/or interlinking between the Union and the national laws,

Figure 1 Normative Picture of the EU Polity as a whole Consisting of interlinking State and Union legal orders

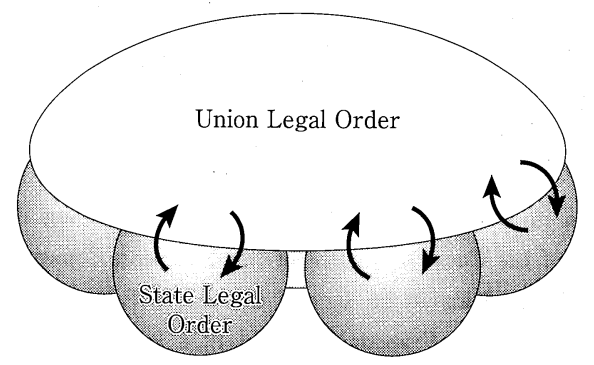


『日本 $\mathrm{EU}$ 学会年報』第 25 号, 平成 17 年 9 月

the process of which may transform the basic legal concepts on which each legal order stands.

1) For my detailed commentary on the main points of the Constitutional Treaty and the full Japanese translation of the whole Treaty and some Protocols of constitutional nature, see Nakamura 2004 [written in Japanese].

2) However, European citizenship is not an independent status but an additional one attached to national citizenship (Art. 17 EC; Art. I-10(1) CT).

3) This point relates to another point, that le pourvoir constituant européen (the original power to constitute a European polity) does not yet exist in legal terms as well as in real terms in the EU.

4) The establishing treaty of the ILO is called "the Constitution of the International Labour Organisation" (1946). Other examples include the UNESCO Constitution (1945) and the WHO Constitution (1948).

5) Another new office called the President of the European Council also represents the EU, but only within the field of the Common Foreign and Security Policy, and that person cannot prejudice the powers of the Union Foreign Minister (Art. I-22(2)).

6) However, some procedural differences in legislation for ex-third pillar matters remain.

7) The only exception is that in the field of CFSP, where adoption of European Laws and European Framework Laws is excluded (Art. I-40(6)).

8) But the decision-making procedure relating to the CFSP as well as the legality of European decisions providing for restrictive measures against natural or legal persons under the CFSP are subject to judicial review by the Court of Justice (Art. III-376).

9) The modification may cause confusion in some cases. For example, the Constitutional Treaty classifies the competition rules for the internal market as "exclusive" competence (Art. I-13), but the previous ruling in 1969 acknowledged parallel national competence (Case 14/68, Walt Wilhelm v. Bundeskartellamt [1969] ECR 1), and the current Council Regulation 1/2003 on the implementation of Community competition rules ([2003] OJ L 1 /1) as well as Art. III-163(e) of the Constitutional Treaty presuppose that parallel existence.

10) E. g., Case 26/62 Van Gend en Loos [1963] ECR 1; Case 6/64 Costa v. ENEL [1964] ECR 585.

11) The Declaration in Article I-6 notes the IGC's understanding that the Article reflects existing case law of the Court of Justice of the European Communities and of the Court of First Instance. It remains to be seen if the future ECJ would take the same view.

12) Cases C-6/90 and C-9/90, Francovich [1991] ECR I-5357; Cases C-46/93 and C-48/93, 
The EU as a Plural Constitutional Order: An approach to the Constitutional Treaty (Nakamura)

Brasserie du Pêcheur [1996] ECR I-1029; Case C-224/01, Köbler [2003] ECR I-10239.

13) Its mission is to support and strengthen coordination and cooperation between national investigating and prosecuting authorities in relation to serious transfrontier crimes (Art. III-273).

14) The Constitutional Treaty reinforces the present arrangements between the Member States in the field of Common Security and Defense Policy (CSDP), based on an intergovernmental procedure. Although the Treaty now requires the Member States to offer their civilian and military capabilities for the implementation of the common security and defense policy (Art. I-41(3)), the implementation is only made possible by the Council's unanimous decision.

15) For European decisions on the CSDP, the ex-Second Pillar mode increases the intergovernmental element, in that only the Union Foreign Minister or a Member State can submit proposals or initiatives to the European Council or the Council (Art. I-41(4)). The Commission is not allowed to put forward any proposal even via the Union Foreign Minister.

16) This is a circular logic concerning the establishment and legitimation of EU autonomy. This is, however, what every basic norm (often called a "constitution") that creates a polity does. A nation-state is freshly constituted because the constitution says so. See, MacCormick 1999: 102-104.

17) Belgium, France, Germany and the Netherlands have similar legal arrangements for collective agreements between management and labour, which can be extended by law to those who are not parties to the agreements (Blanpain 2002:25). However in Denmark, Italy and the UK, this extension is not allowed in law (Kenner 2003:264).

18) In the area of economic policy coordination, the Member States coordinate their economic policies and supervise any excessive deficit of any Member State in the Council by a special qualified majority (two thirds of the weighted votes) (Art. 104 EC). Thus, in this area, the system is still under the political control of the States, but being legally constructed, any violation of the due process prescribed in the EC Treaty would be annulled by the Court of Justice. See Case C-27/04 Commission v. Council [2004] ECR I-(not yet reported) (13 Jul. 2004, ECJ) : the Court annulled the Council decision which put excessive deficit procedures against Germany and France in abeyance in contravention with the Treaty provisions.

19) Protocol on the application of the principles of subsidiarity and proportionality.

20) By the same token, so-called ex-post supervision is another example of interface. Its purpose is to give the national Parliaments a way of challenging European legislative acts that they allege violate the subsidiarity and proportionality principles (Art. 7 Prot.).

21) Implementation of Union law through "comitology" appears similar to the networking I discuss here, but the comitology mainly concerns the implementation phase whereas the 
『日本 $\mathrm{EU}$ 学会年報』第25号, 平成17年 9 月

networking is directly involved in the phases of legislation as well as implementation of law and policy. This is because the national authorities and the Council or the Commission are networked and the former can directly suggest legislative initiative to the latter Union institutions. For comitology, see, Pedler and Schaefer 1996; Joerges and Vos 1999; Andenas and Türk 2000. The Constitutional Treaty does not specifically deal with comitology.

22) The Constitutional Treaty recognises the method of two types:(a) the Council led type, and (b) the Commission led type. In the Council led type, the Council issues guidelines and supervises national specific policies and performances by the Member States. In the Commission led type, the Commission does those tasks. The Council led type is applied in the areas of Economic Policy (Art III-179), and Employment (Art. III-206). The Commission led type is applied in the areas of Social Policy (Art. III-213), Public Health (Art. III-278(2)), Industry (Art. III-279(2)), Research and Technological Development (Art. III-250(2)), and Trans-European Networks (Art. III-247(3)).

\section{Bibliography}

Andenas, Mads. And Alexander Türk. 2000. Delegated Legislation and the Role of Committees in the EC. The Hague: Kluwer Law International.

Arnull, Anthony. 2004. The Member States of the European Union and Giscard's Blueprint for its Future. Fordham International Law Journal 27:503-543.

Barents, René. 2004. The Autonomy of Community Law. The Hague:Kluwer Law International.

Blanpain, Roger. 2002. Involvement of Employees in the European Union. The Hague: Kluwer Law International.

Bliss, Howard. (ed.) 1970. The Political Development of the European Community:A Documentary Collection. Waltham, Mass.: Blaisdell Publishing Co.

Cygan, Adam Jan. 1998. The United Kingdom Parliament and European Union Legislation. The Hague: Kluwer Law International.

Denza, Eileen. 2002. The Intergovernmental Pillars of the European Union. Oxford: Oxford University Press.

FIDE. 2002. FIDE XX Congress London 30 October-2 November 2002. vols. I and II. London:British Institute of International and Comparative Law.

Haekkerup, Nick. 2001. Controls \& Sanctions in the EU Law. Copenhagen:DJØF Publishing. Harryvan, Anjo G. and Jan van der Harst (eds.) 1997. Documents on European Union. Houndsmills : Macmillan.

Hartley, Trevor C. 1999. The Constitutional Problems of the European Union. Oxford: Hart Publishing. 
The EU as a Plural Constitutional Order: An approach to the Constitutional Treaty (Nakamura)

Hartley, Trevor C. 2001. The Constitutional Foundations of the European Union. Law Quarterly Review 117:225-246.

Hartley, Trevor C. 2004. European Union Law in a Global Context. Cambridge: Cambridge University Press.

Joerges, Christian and Ellen Vos. 1999. EU Committees: Social Regulation, Law and Politics. Oxford : Hart Publishing.

Kenner, Jeff. 2003. EU Employment Law. Oxford: Hart Publishing.

La Torre, Massimo. 1999. Legal Pluralism as Evolutionary Achievement of Community Law. Ratio Juris $12: 182-195$.

MacCormick, Neil. 1999. Questioning Soverignty:Law, State, and Nation in the European Commonwealth. Oxford; Oxford University Press.

Mancini, Federico G. 2000. Democracy and constitutionalism in the European Union. Oxford: Hart Publishing.

Nakamura, Tamio. 1993. The Decline of Parliamentary Sovereignty: Constitutional Change in Britain since its Accession to the European Community. Tokyo:University of Tokyo Press. [中村民雄『イギリス憲法と EC 法一国会主権の原則の调落』(東京大学出版会, 1993 年)]

Nakamura, Tamio. 2003. The Direction of the European constitution after the Nice Treaty. In Koji Fukuda and Hiroya Akiba (eds.), European Governance After Nice. London: Routledge Curzon. 3-18.

Nakamura, Tamio. 2004. The EU Constitutional Treaty: Commentary and Translation. The House of Representatives of Japanese Diet, Research Commission on the Constitution Document No. 56. [鼻議院憲法調査会事務局（中村民雄執筆）『欧州憲法条約一解説及び翻訳 一』(衆囊資第56号)]

Nelsen, Brent F. and Alexander C-G. Stubb (eds.). 1998. The European Union. 2nd ed. London: Lynne Rienner.

O'Neill, Michael 1996. The Politics of European Integration. London: Routledge.

Pedler, Robin. H. and Günther F. Schäfer. 1996. Shaping European Law and Policy: The Role of Committees and Comitology in the Political Process. Maastricht:European Institute of Public Administration.

Usui, Yoichiro. 2003. Evolving Environmental Norms in the European Union. European Law Journal. $92: 69-87$.

Van Caenegem, R. C. 1995. A Historical Introduction to Western Constitutional Law. Cambridge: Cambridge University Press.

Walker, Neil. 2003. Late Sovereignty in the European Union. In. N. Walker (ed.) Sovereignty in Transition. Oxford: Hart Publishing. 3-32.

Weiler, Joseph. H. H. 1999. The Constitution of Europe: "Do the new clothes have an emperor?" and other essays on European integration. Cambridge: Cambridge University 
『日本 $\mathrm{EU}$ 学会年報』第25号, 平成17年 9 月

Press.

Weiler, Joseph. H.H. 2003. In defence of the status quo:Europe's constitutional Sonderweg. In Weiler and M. Wind (eds.), European Constitutionalism Beyond the State. Cambridge: Cambridge University Press. 7-23.

Winterton, George. 1976. The British Grundnorm:Parliamentary Supremacy Re-examined. Law Quarterly Review 92:591-617.

\section{Official Documents}

Cmnd. No. 3301. 1967. Legal and Constitutional Implications of United Kingdom Membership of the European Communities. London:HMSO.

Cmnd. No. 6003. 1975. Membership of the European Community: Report on Renegotiation. London: HMSO. 


\title{
The EU as a Plural Constitutional Order:An approach to the Constitutional Treaty
}

\author{
NAKAMURA Tamio
}

The present paper argues that the EU is a new type of non-state polity in which the Member State constitutional order and the Union constitutional order compete as well as complement each other. The paper first categorises four main approaches to the EU polity analysis: State Sovereignty Approach, Super-State Approach, Functional State Approach and Non-State Polity Approach. Then the paper discusses various legal aspects of the Constitutional Treaty to analyse which of the four approach best captures the unique legal features of the EU as well as the political practices that have been taken so far. In brief, State Sovereignty Approach captures well the Member States' ultimate EU polity making power, but fails to recognize the on-going polity making by other fully entitled actors including the European Parliament. Super-State Approach does not correspond to the legal settings that the Constitutional Treaty stipulates, nor does it correspond to the political reality of current Europe: there seems no Member State or majority of Union citizen that want a European level nation-state. Functional State Approach, on the other hand, captures well the EU's functional similarity to a state. However that approach also faces the inconsistency between the legal provisions of the Constitutional Treaty and the functional reality:there is no formal suggestion or stipulation in the Constitutional Treaty that the EU would supersede the Member States to form a single state (with or without creating a "nation" at European level). In the end, therefore, the current 
and the future EU under the Constitutional Treaty are at best captured as a non-state polity at European level. However, it is the present paper's contention that the legal analysis of this polity suggests that the EU legal order is not a unitary legal order, but is consisted of two different kinds of constitutional orders: Union's and the Member States'. The Member States' constitutional order still construct a nation-state polity based on "sovereignty" concept, whereas the Union's constitutional order seeks to build a non-state polity without relying on "sovereignty" concept.

These heterogeneous constitutional orders complement as well as compete to create new legal rules and concepts that suit this new type of mixed polity as a whole. 